\title{
Forums as a tool for negotiating knowledge in Higher Education
}

\author{
Manuela Fabbri ${ }^{\text {a }}$
}

${ }^{a}$ University of Bologna, Italy,m.fabbri@unibo.it, ORCID 0000-0001-7037-5746

\begin{abstract}
This article discusses an innovative educational experience carried out as part of teaching of the module 'Technologies of Education' to third-year students completing the 'Expert in Social and Cultural Education' course in the Department of Education Studies at the Bologna and Rimini campuses. The experience examined the use of an online forum as a virtual environment for interactions between students. This experience is based on the hypothesis that significant knowledge can be gained by taking part in learning communities. In particular, this can occur within a deliberately educational digital environment that allows for individual learning to be given a new meaning, thanks to contributions from other participants, which, precisely because of its asynchronous nature, encourages reflective thought. The results are in line with studies that reveal the positive potential of forums: they are shown to be an effective environment for collaborative negotiation and the consolidation of knowledge, as well as for meta-reflection, as they enable topics previously dealt with in the classroom environment to be resumed and reformulated in the context of group discussion.
\end{abstract}

Keywords: Blended Learning, Higher Education, Knowledge Building Community.

\section{Theoretical framework}

Different approaches of group knowledge building in learning communities are the subject of a considerable number of research studies, in line with the modernisation of education as provided for by Italian legislation (L. 107/2015) and by various EU initiatives.

On the basis of the assumption that online forum discussion can, along with the use of specific teaching strategies, support the process of negotiation as well as collaborative knowledge-building (Scardamalia \& Bereiter, 1992; 1994; Muukkonen et al., 1999; Cacciamani et al., 2013) by involving students in the three dimensions of learning (knowledge, social and motivational, Wilson \& Whitelock, 1997), the main objective of this study is to monitor the process of negotiating knowledge by analysing the quality of interactions within a forum that acts as a further environment (in addition to the classroom) for communication between students on a university course. Some authors refer to overcoming social constructivism and moving towards an approach that is considered to be more complex, ecosystemic and enactive, where 'the focus moves from the noun to the verb, from knowledge to constructing, from theory to a recursive process. In such a process, the verb describes the act of overcoming the boundary in which are determined both the construction of world and the construction of identity, a recursive process in which presence is intrinsically connected to separation' (Rossi, 2009, p.63). These theories consider the construction of important networks between the members of a learning community to be the link and essential foundation for the collaborative development of knowledge.

The initial hypothesis, which picks up on some considerations from literature on constructivist digital learning environments (Calvani \& Varisco, 1995; Wenger, 1998; Guerra, 2002; Ardizzone \& Rivoltella, 2003; Calvani, 2005; Trentin, 2005) and post-constructivism (Rossi, 2009), in line with the principle of knowledge building community (Scardamalia \& Bereiter, 2003), is that significant knowledge can be acquired by participating in a learning community. In particular, this can occur within a deliberately educational digital environment that allows for individual learning to be given new meaning, thanks to contributions from other members, which, precisely because of its asynchronous nature, encourages reflective thought (Schön, 1993; 2006). 


\section{Context and teaching environment}

The innovative educational experience, which is the subject of this study, was carried out during the 2016-2017 academic year as part of the teaching of the module 'Technologies of Education' to third-year students completing the 'Expert in Social and Cultural Education' course in the 'Giovanni Maria Bertin' Department of Education Studies at the Bologna and Rimini campuses. The course, which used the blended learning method, was divided between classroom teaching (two-thirds of the course hours) with interactive lessons and group work and e-learning, using the educational materials provided by the teacher within a dedicated area of Bologna University's Moodle platform. The e-learning element of the course included, alongside multimedia materials and activities on the innovative teaching at school and outside school, two types of forums: a more traditional forum titled 'Cyberbullying' and another, which is the subject of this study, more closely connected to theories of social constructivism (Jonassen, 1994; Pontecorvo, et al., 1995; Varisco, 2002) and called the 'virtual space for building knowledge'.

\section{Participants}

The experience studied the use of the asynchronous forum application as a virtual environment for interaction and communication between university students. The 131 students on the course, divided equally between the campuses of Bologna (48\%) and Rimini (52\%) were involved in activities of knowledge negotiation through interaction with peers within the 'virtual space for building knowledge'.

The sample is characterised by a very high proportion of female students to male students, representing $95 \%$ and $85 \%$ at Bologna and Rimini campuses, respectively: this reflects the high proportion of female students who choose courses relating to professions in education, evidently not limited to school education. Forum participation was a compulsory task for the purposes of passing the examination: each of the students had to post at least two contributions in the various topics proposed by the teacher. The quantitative analysis of the data reveals good forum participation that exceeded the compulsory level: at both campuses, the number of contributions was around one-third more than the minimum required by the teacher (162 posts at Rimini campus and 160 posts at Bologna campus).

\section{The role of a teacher}

The role of a teacher in the forums was to attend and accompany students, acting respectfully of their autonomy, according to the didactic novelty of the methodological tool provided and acknowledging the teaching experience offered within an institutional context in which it still persists, in the students' habits, the traditional learning method. Particular attention was paid to not making the teacher's intervention (online and in the classroom) perceived as immediately evaluative, with the risk of discouraging students' motivation to provide their own opinion. The teacher has partly taken on the role of animator/moderator of the community with pedagogical-intellectual and methodological support function (Rotta \& Ranieri, 2005). In particular, taking up the model of the Community of Inquiry by Garrison, Anderson and Archer (2000), the teacher focused on the teaching presence or rather on the definition of design, facilitation and direction of cognitive and social processes: during the course of the teaching, multimedia arguments and challenges were presented, following up on some aspects that had emerged in discussions (plenary or in small groups) between students in the classroom, which encourages the continuation of interactions using the digital environment as a further space for detailed study of the topics (facilitating discourse). Furthermore, methodological scaffolding instruction, albeit partial and purely methodological, was used in the classroom during lessons and by creating, around halfway through the course, a topic called 'General comments on participation' in which the students were reminded of the value of both discussion and reflection in the environment they were using, together with the need to provide sources of information and cited documents so that other students could also consult them (design and organisation).

\section{Materials and tools}

The digital language used for the topics in the forum aimed to bring into play the potential and educational value of communication channels in online transmedia environments (Jenkins, 2006) by presenting different linguistic codes (written, oral, audio and visual) and different media channels (text, music and audiovisuals). Different cultural genres were also represented: for example, we pass from 'popular' culture, with the 2016 summer song by J-Ax and Fedez in the Dancehall reggae genre, to a much more highbrow genre represented by a piece by Luigi Pirandello, the great 20 thcentury Italian dramatist, writer and poet. Both pieces, in clearly different ways, reflect on the problematic relationship between people and technology in contemporary society and in the past. This study analyses the discussion threads of 
the two aforementioned topics insofar as they are representative in terms of quantity (145 of 322 contributions) and reveal two complementary ways of using digital language, both strongly present (although probably to different degrees) in the daily patchwork of linguistic codes used by the students.

\section{Methodology}

Following the examination of the principles put forward in scientific literature on the participatory aspects of learning in computer-supported collaborative learning (CSCL) environments (Henri, 1992; Cesareni, et al., 2001; Garrison \& Anderson, 2003; Cesaresi \& Martini, 2005; Pozzi et al., 2007; Cacciamani \& Ferrini, 2007; Cacciamani et al., 2012), it was decided that the analysis would focus on the content of contributions using an encoding scheme made up of a content-related part (Table 1) and an interactional part (Table 2), with the aim of measuring the attitudes of future social and cultural educators with regard to technology, together with the type of interactions that took place.

Table 1. The content-related part.

\begin{tabular}{|l|l|l|}
\hline \multicolumn{2}{|c|}{ Model of pedagogic interpretation } \\
\hline $\begin{array}{l}\text { Integrated posts: } \\
\text { contributions that display a preliminarily } \\
\text { positive attitude to ICT }\end{array}$ & $\begin{array}{l}\text { Posts that refer to precise } \\
\text { information }\end{array}$ & $\begin{array}{l}\text { Contributions that include information taken } \\
\text { from specifically cited sources, such as } \\
\text { newspaper articles } \\
\text { scientific essays } \\
\text { narrative pieces }\end{array}$ \\
\cline { 1 - 1 } $\begin{array}{l}\text { Apocalyptic posts: } \\
\text { contributions that display a biased and } \\
\text { defensive attitude to ICT }\end{array}$ & & $\begin{array}{l}\text { - legislative documents } \\
\text { - iconographic materials } \\
\text { audio materials } \\
\text { video materials }\end{array}$ \\
\cline { 3 - 4 } $\begin{array}{l}\text { Problematist posts: critical contributions } \\
\text { that evaluate the positive and negative } \\
\text { elements of ICT }\end{array}$ & $\begin{array}{l}\text { Posts that are founded on } \\
\text { professional expertise }\end{array}$ & $\begin{array}{l}\text { - Contributions in which the student makes } \\
\text { reference to key words related to the } \\
\text { professionalism of social and cultural } \\
\text { educators } \\
\text { Contributions in which the student makes } \\
\text { reference to practices related to the } \\
\text { professionalism of social and cultural } \\
\text { educators }\end{array}$ \\
\hline
\end{tabular}

For the analytical framework of the content-based aspect, contributions were catalogued according to three categories: those of individuals who accept almost without criticism the use of new technologies ('integrated'), those of individuals who predominantly warn against the risks associated with new technological environments ('apocalyptic') and, lastly, those who deal with the topic in a reflective and critical way, taking into consideration the aspects of positive innovation and the potential negative consequences ('problematist'). This division into three categories, together with their relative sub-criteria, partly follows on from the division proposed by the author in a previous experience (Fabbri, 2009). ${ }^{1}$

Table 2. Interactional part.

\begin{tabular}{|c|c|c|}
\hline Conversational type & Global conversational functions & Specific conversational functions \\
\hline \multirow[t]{2}{*}{$\begin{array}{l}\text { Post that establishes a relationship } \\
\text { exclusively with the teacher }\end{array}$} & $\begin{array}{l}\text { Post that only responds to the teacher's } \\
\text { topic }\end{array}$ & $\begin{array}{l}\text { Provides an individual's own contribution } \\
\text { Provides examples from personal experience } \\
\text { Provides information obtained in the } \\
\text { classroom } \\
\text { Refers to literature on the topic }\end{array}$ \\
\hline & $\begin{array}{l}\text { Post that introduces new issues, } \\
\text { theories and information }\end{array}$ & $\begin{array}{l}\text { Presents an individual's own idea/theory } \\
\text { Provides scientific information } \\
\text { Provides examples from personal experience } \\
\text { Provides information obtained in the } \\
\text { classroom } \\
\text { Formulates problems }\end{array}$ \\
\hline $\begin{array}{l}\text { Post that establishes a relationship } \\
\text { exclusively between students }\end{array}$ & \multirow[t]{2}{*}{$\begin{array}{l}\text { Post that refers to and/or re-elaborates } \\
\text { theories or information provided by } \\
\text { other students }\end{array}$} & $\begin{array}{l}\text { Provides an individual's own contribution } \\
\text { Re-elaborates someone else's contribution } \\
\text { Summarises the discussion } \\
\text { Repeats someone else's contribution (without } \\
\text { elaboration) }\end{array}$ \\
\hline Post that establishes a relationship & & $\begin{array}{l}\text { Repeats own contribution (without } \\
\text { elaboration) }\end{array}$ \\
\hline
\end{tabular}

\footnotetext{
${ }^{1}$ In this study, still mostly exploratory, it was not considered the analysis of the permanence of the single student in each class, limiting ourselves to carry out the classification in relation to the single group of interventions.
} 


\begin{tabular}{|l|l|l|}
\hline $\begin{array}{l}\text { with both the teacher and the other } \\
\text { students }\end{array}$ & $\begin{array}{l}\text { Post that introduces new issues, } \\
\text { theories and information }\end{array}$ & $\begin{array}{l}\text { Presents an individual's own idea/theory } \\
\text { Provides scientific information } \\
\text { Provides examples from personal experience } \\
\text { Provides information obtained in the } \\
\text { classroom } \\
\text { Formulates problems }\end{array}$ \\
\hline
\end{tabular}

With regard to the interactional part (Cesaresi \& Cacciamani, 2015), the posts were classified into three categories: firstly, contributions of a responsive or creative nature that were exclusively addressed to the teacher; secondly, responsive or creative posts that formed part of a discussion between students and that did not analyse the topic proposed by the teacher; whilst the third and final category included any responsive or creative posts that responded to the teacher's topic and, at the same time, formed part of a discussion with other students.

\section{Results}

Looking at the types of posts (Fig. 1), the study reveals a very low number of posts that are uncritically accepting of the introduction of new technologies in our daily lives, whereas a high percentage of posts (58\%) fall into the category of problematist posts, insofar as they relate to students who deal with the issue of ICT in a critical and reflective way, evaluating the positive elements of innovation and the potential negative consequences. More than one-third of the posts are classified as apocalyptic insofar as they mainly focus on the risks associated with new technological environments.

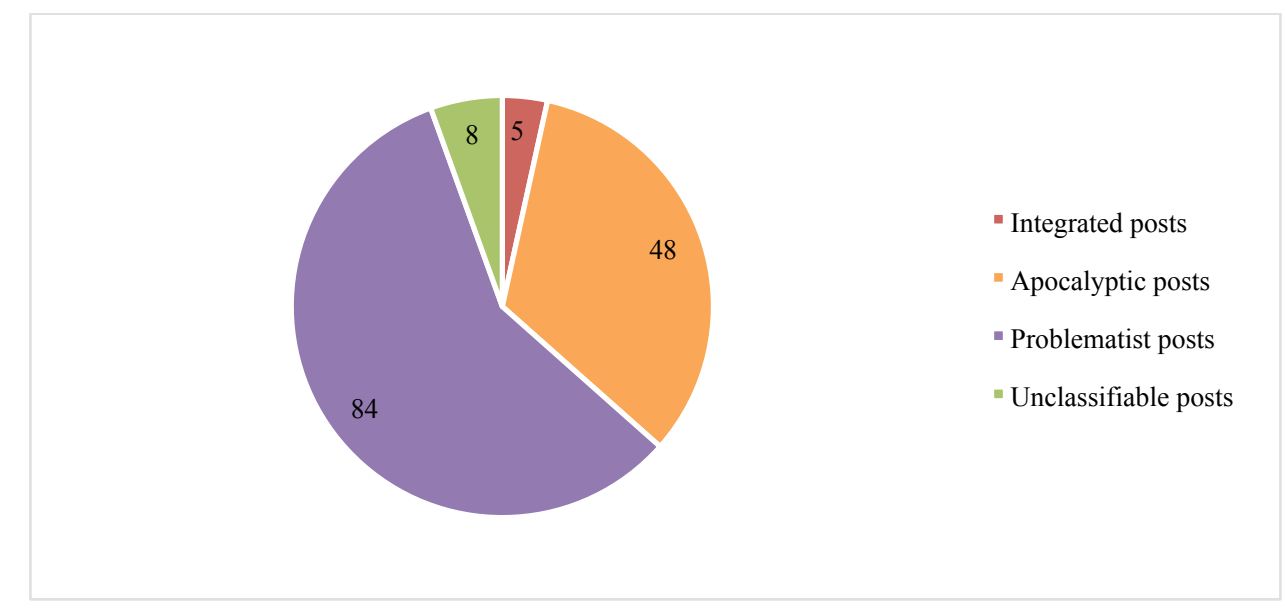

Fig 1. Types of posts from students at Bologna and Rimini campuses in response to the topics 'Vorrei ma non posto' and 'Quaderni di Serafino Gubbio operatore'

In general, the data regarding the quality of contributions were quite positive (Fig. 2): 55\% of posts were of good quality in terms of their content, either backed up with precise information or displaying expertise relating to the professionalism of educators. In fact, these students were in their third year of the bachelor degree course in Social and Cultural Education and, therefore, had already completed a substantial part of this educational programme.

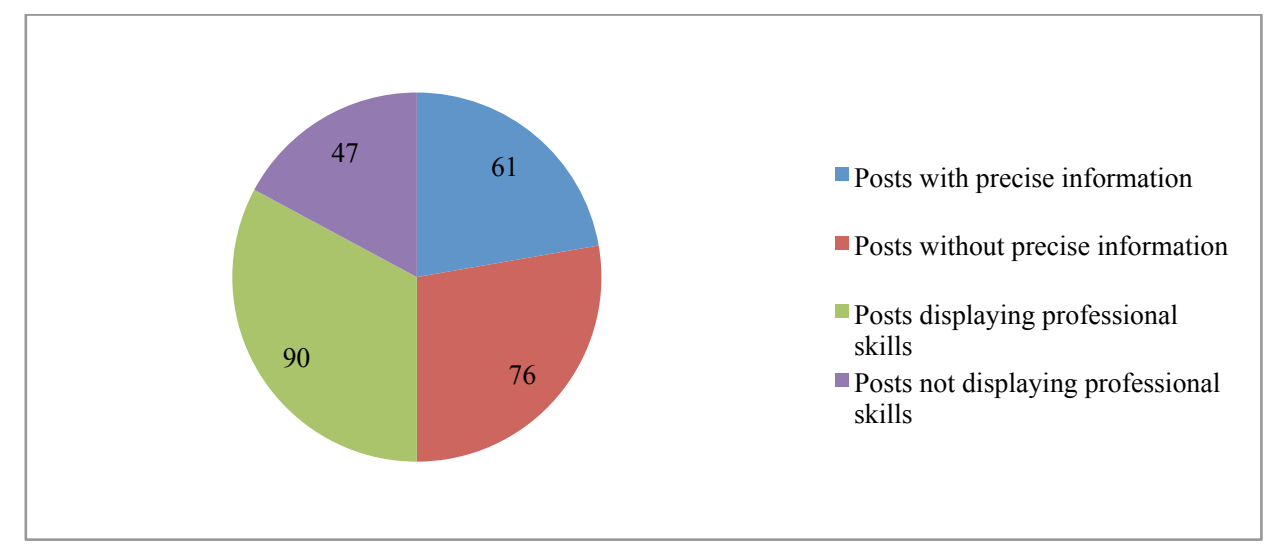

Fig. 2. Quality of integrated, apocalyptic and problematist posts. 
We will now analyse and compare data from the two predominant post types that made up the contributions: apocalyptic and problematist posts. ${ }^{2}$

Whilst just more than one-third of the apocalyptic posts included precise information, the number of problematist posts in this category exceeded $50 \%$ (Fig. 3).

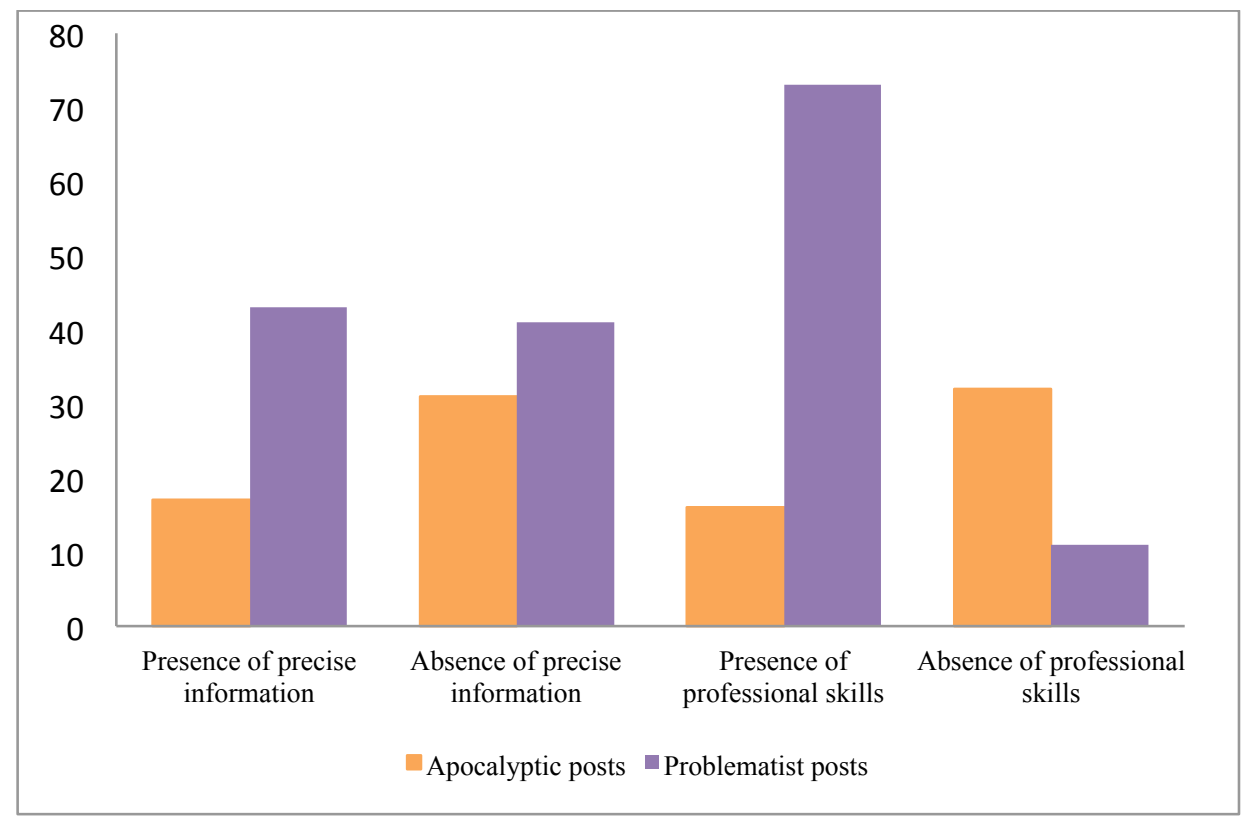

Fig. 3. The presence of precise information and display of professional skills in the apocalyptic and problematist posts.

If we compare the various types of material that are referred to in these posts (Fig. 4), we find vast differences between the apocalyptic and problematist posts.

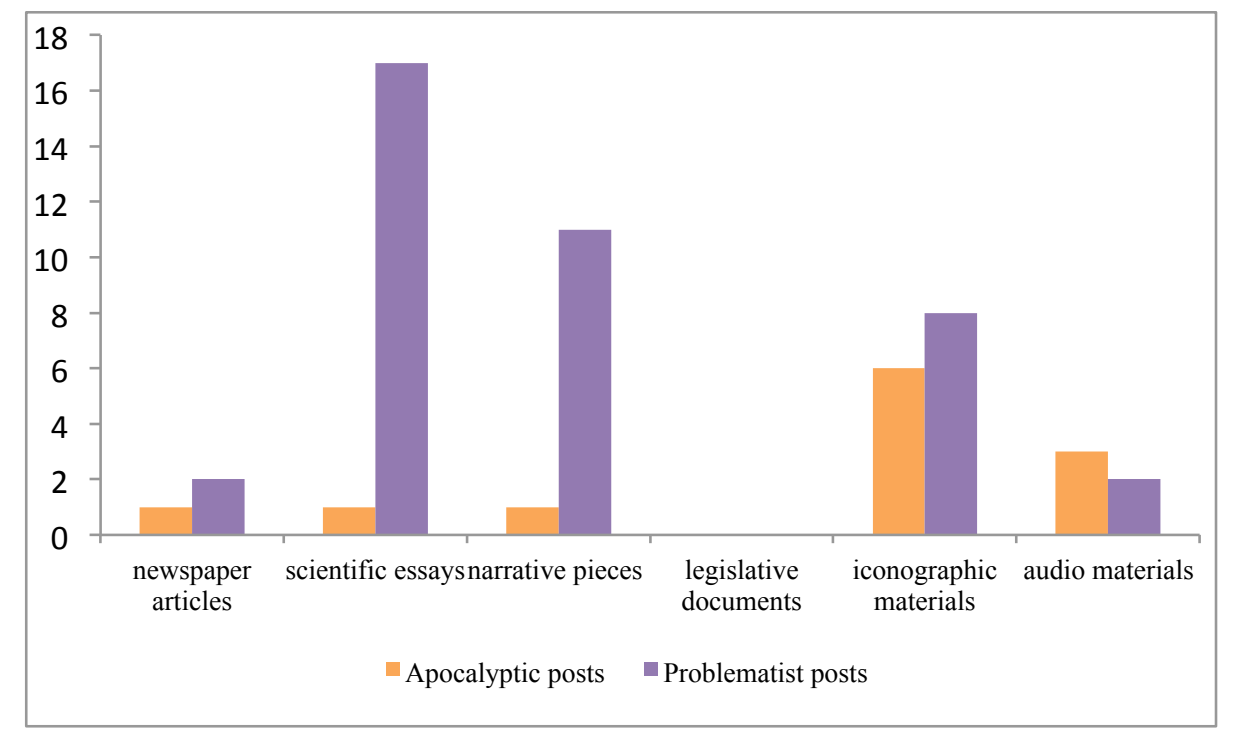

Fig. 4. Type of precise information in the apocalyptic and problematist posts.

An overwhelming majority of the apocalyptic posts $(87 \%)$ refer to video materials (most of which are from YouTube), iconographic and audio materials; there are almost no posts that cite more authoritative sources, such as scientific papers, legislative documents, narrative pieces or newspaper articles (paper or online versions). The situation changes when we look at the posts from students with a problematist attitude to ICT: in more than half of these

\footnotetext{
${ }^{2}$ From this point on, we will look exclusively at the two above-mentioned types of contributions, because of the fact that there were so few integrated posts.
} 
contributions, they base their arguments on scientific essays (31\%), narrative pieces (20\%) and newspaper articles (paper or online, $4 \%$ ), whilst only $35 \%$ of posts make reference to audiovisual and iconographic materials.

Lastly, considering the display of professional expertise in both the apocalyptic and problematist posts, there is a further notable discrepancy (Fig. 3) between them: $87 \%$ of the problematist posts display professional skills $(71 \%$ of which are supported by the use of keywords relating to the professionalism role of educators and $23 \%$ of which also present genuine and practical educational proposals) compared to $33 \%$ of apocalyptic posts.

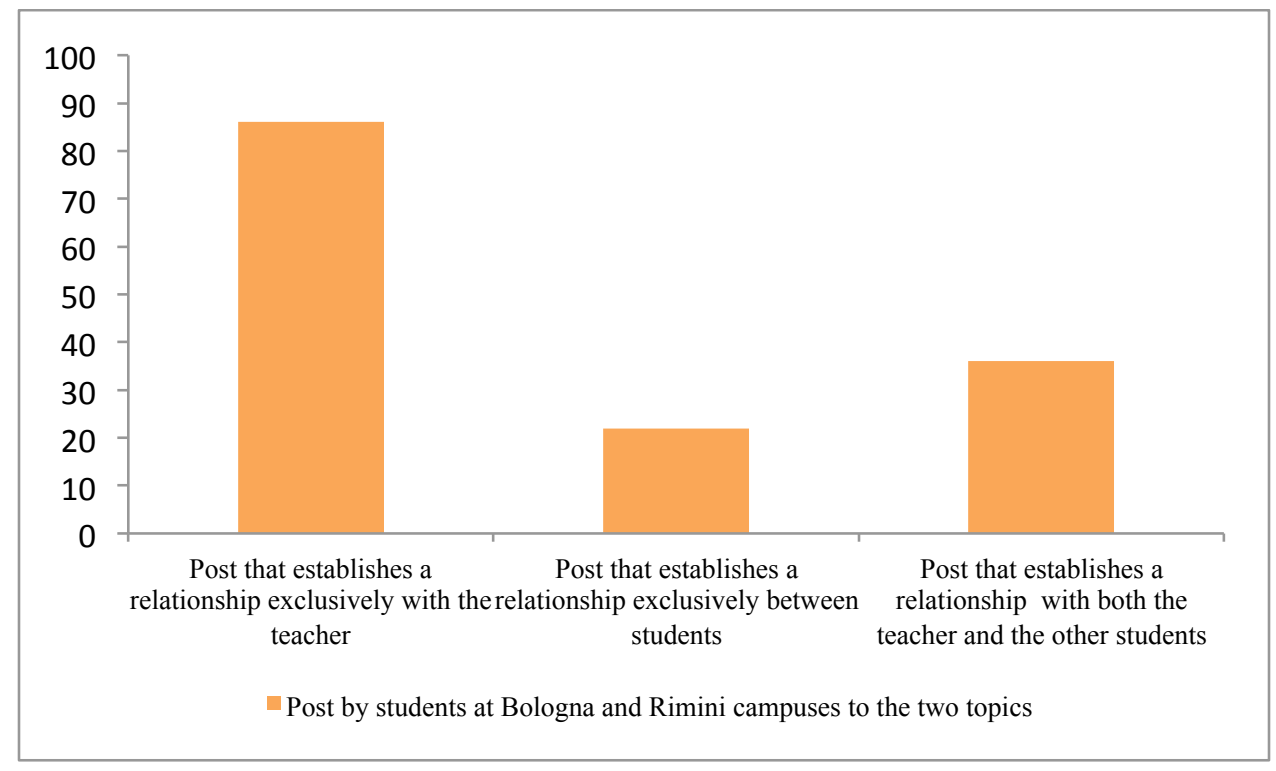

Fig. 5. Type of interaction of contributions made by students at Bologna and Rimini campuses to the two posts.

Moving on to analyse the type of interactions made by students and taking into consideration all 145 posts on the two topics (Fig. 5), we can see that $60 \%$ of the posts exclusively address the teacher responding to the specific topic as if it were an individual task in itself. This is despite the fact that the teacher specified in the task, and repeatedly highlighted during lessons, the communicative and reflective nature of the forum environment and the need to participate by taking part in discussions as active members of the virtual community. The remaining $40 \%$ of the posts can be considered as positive responses to the task insofar as they establish a relationship with both the teacher and the other students (25\%) or are addressed exclusively to peers $(15 \%)$.

It is interesting to see the results that emerge when we look specifically at the 56 posts by students at Bologna campus to the topic 'Vorrei ma non posto' (Fig. 6): the percentage of contributions that make the most of the forum's opportunity for knowledge negotiation increases to $62 \%$, compared to $38 \%$ of posts that reply exclusively to the teacher, in contrast to the other three threads that were analysed. The interactions displayed in this specific thread stand out because they offer stimulating, dialectical and interested comparisons and playful tones, as a result of both the informal nature of the topic and the presence within the group of a senior student who took on the role of a teacher, making 12 contributions to the discussion, asking for clarification from peers and encouraging student participation. 


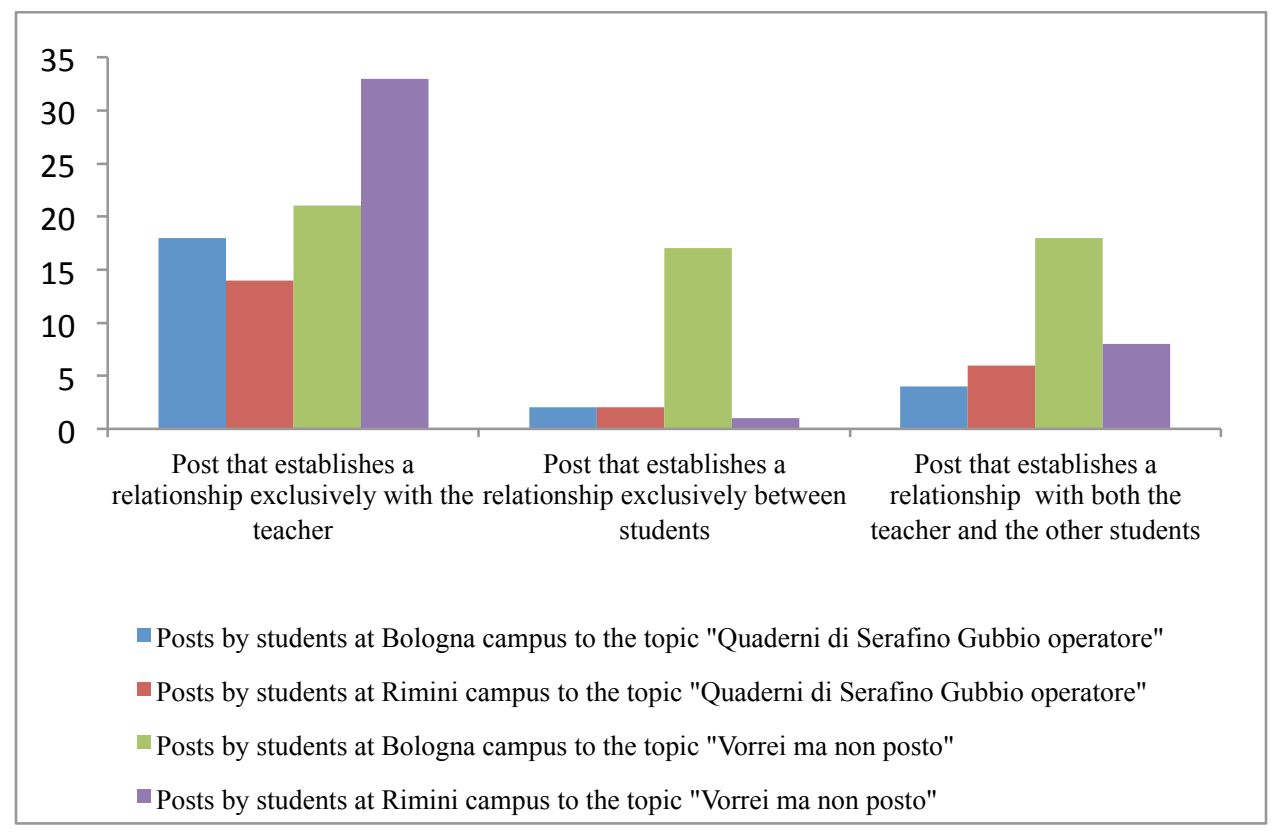

Fig. 6. Type of interaction of contributions made by students at Bologna and Rimini campuses to the teacher's two topics.

An overwhelming majority of the contributions exclusively address that the teacher stand out as being merely responsive (66\%), whereas only one-third (34\%) can be classified as creative (Fig. 7).

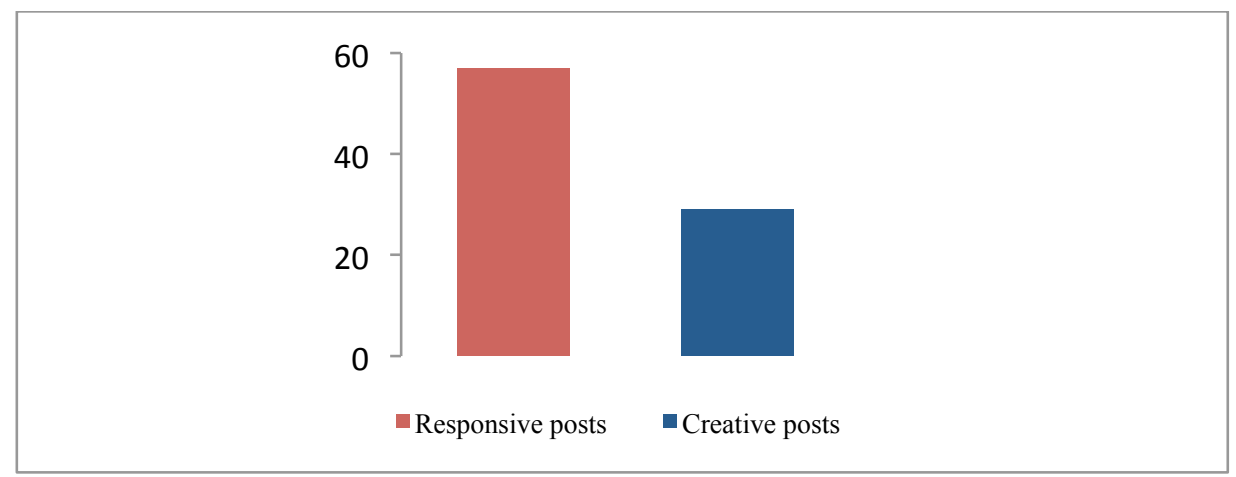

Fig. 7. Types of posts that exclusively address the teacher.

In particular, the majority of responsive posts limit themselves to presenting a point of view by commenting on the topic presented by the teacher, whilst only a quarter also present an individual's own experience, and only a fraction of these arguments are supported by references to scientific literature (Fig. 8). 


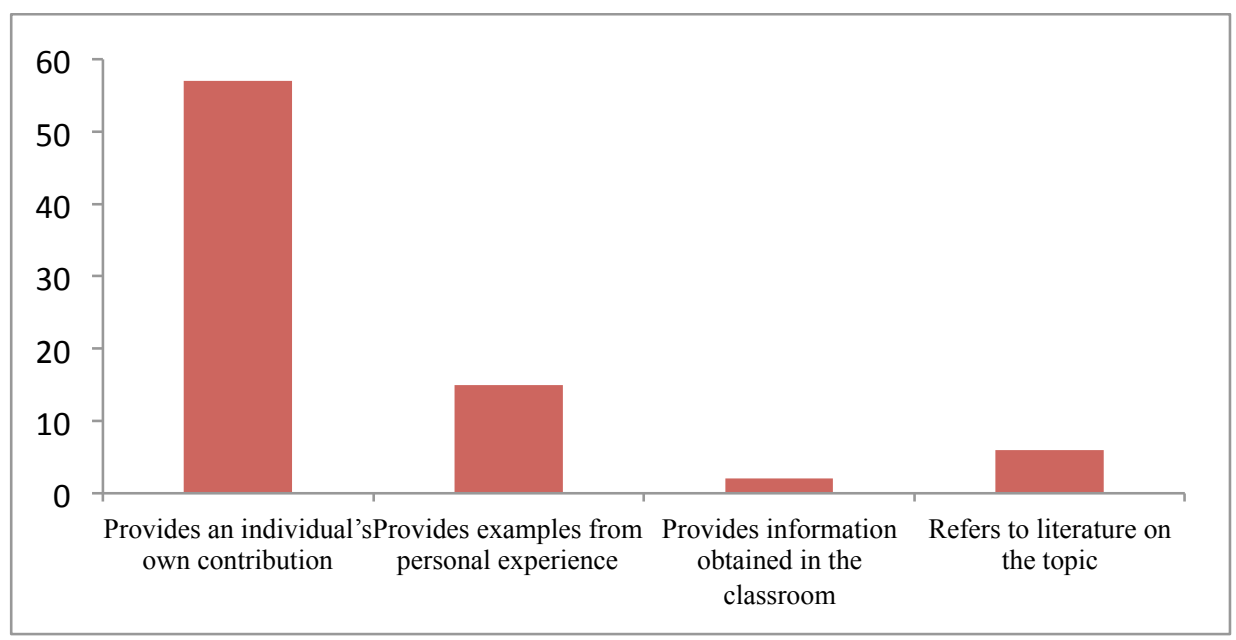

Fig. 8. Types of responsive posts that exclusively address the teacher.

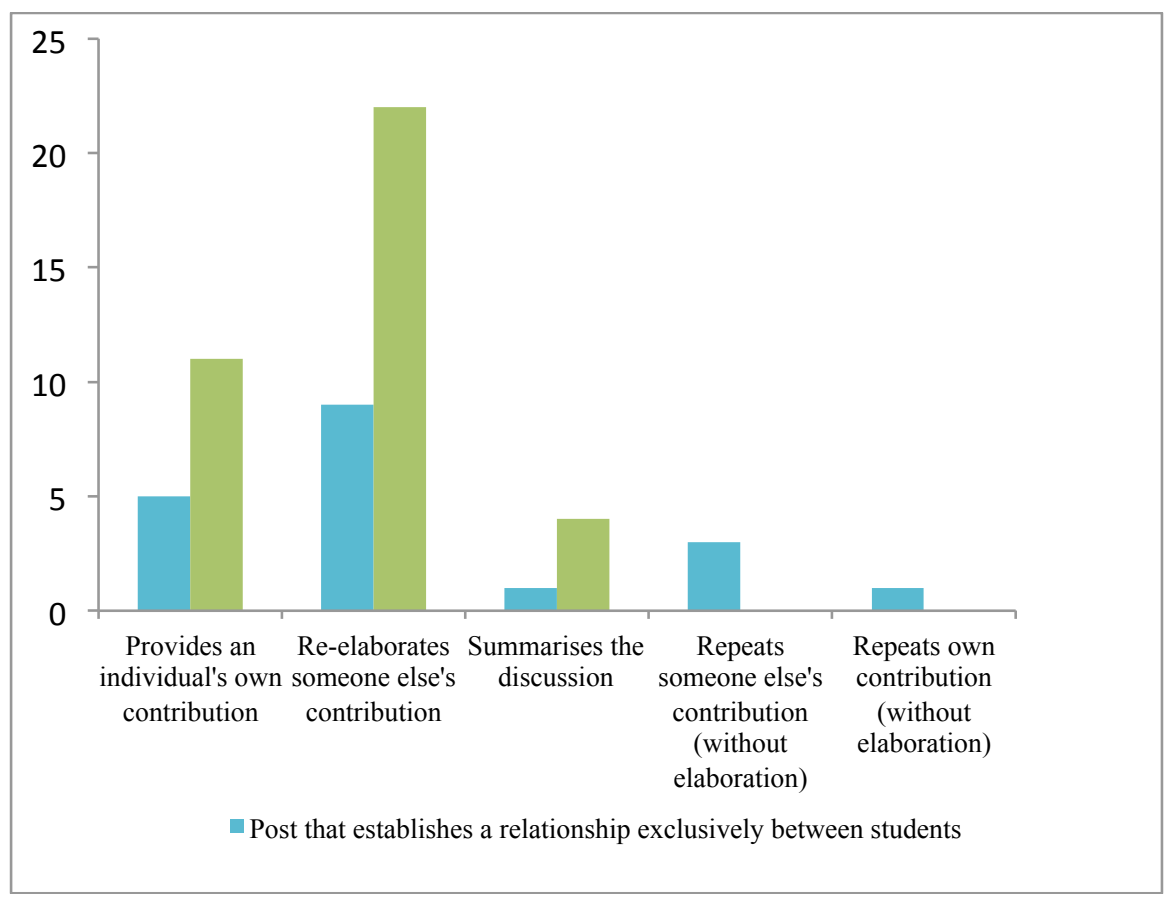

Fig. 9. Types of responsive posts that respond exclusively to other students and responsive posts that respond to both the teacher and other students.

Of the responsive contributions that refer exclusively to posts by other students without specific reference to the topic proposed by the teacher (Fig. 9), a reasonable number (48\%) contain re-elaborations of arguments put forward by other students, a lower percentage (26\%) provide new input, whilst almost none of the posts offer a summary of the discussion (5\%) or are characterised by the repetition, without any elaboration, of their own point of view (5\%), whereas the remaining $16 \%$ present someone else's point of view without elaboration. The situation differs very little if we look at the responsive posts by students who refer to both the teacher's topic and the arguments put forward by other students: more than half (59\%) contain a re-elaboration of an idea put forward by other students, one-third $(30 \%)$ provide new input, whereas a minority $(11 \%)$, although this is double the percentage for the previous type of post, summarise the discussion. There are no posts that offer a mere repetition of one's own or someone else's point of view. 


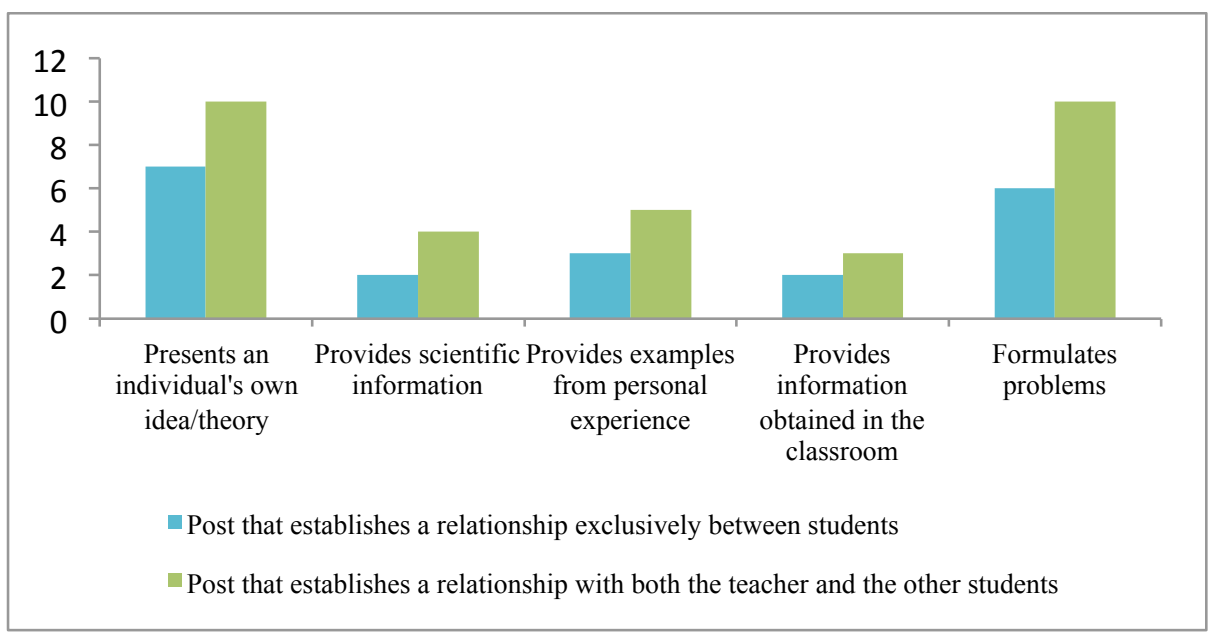

Fig. 10. Types of creative posts that respond exclusively to other students and creative posts that respond to both the teacher and other students.

There is no significant difference if we look at the creative posts by students that have made the most of the forum's intrinsic features for negotiating knowledge through interaction with other students (Fig. 10): in both groups, around one-third put forward new ideas or theories, one-third formulate new issues, $15 \%$ contain information from personal experience and the remaining posts are equally split between those providing scientific information obtained in the classroom and scientific information from the individual's own personal culture and learning experience (including their university education).

\section{Conclusions}

The results that have emerged from this study are in line with previous experiences that have revealed the positive potential of forums: they are shown to be an effective environment for the collaborative negotiation and consolidation of knowledge as they enable topics previously dealt with in the classroom environment to be resumed and reformulated in the context of group discussion. Forums also enable new information to be acquired and the broadening and integration of individuals' existing knowledge. Furthermore, thanks to the prevalence of text as the form of communication as well the asynchronous nature of interactions, the forum environment appears to be a valid tool for encouraging individuals' reflection and cognitive flexibility with regard to both their own opinions and those of others.

Using the digital environment provided, the students have demonstrated a good ability both to engage with topics proposed by others as well as put to forward new suggestions, often in a precise and competent way, together with a willingness to get involved by participating and posting their opinions in such a way $(+23 \%)$ that exceeded the required minimum, in particular, 31 of the 131 students participated surpassing the minimum set by the teacher, with an average of 1.9 more interventions each.

Furthermore, it appears to exist a correlation between students' attitude towards ICT and the form of writing, on the one hand, and the argumentative quality, on the other hand, as already noted with reference to Fig. 3 and 4, whilst the content of apocalyptic posts often appears to be a mere reproduction of products found on the web without specific cultural and scientific references (online newspaper articles, images and audiovisual material), the one brought by problematist posts seems mainly inclined to have a critical and reflective approach, recalling and commenting scientific material as well as supporting their views with a good quantity of good-quality precise information and displaying professional skills that are relevant to social and cultural education.

There was a high percentage of posts that directly addressed the teacher without referring to or considering the opinions of colleagues. This presents a contrast to the familiarity and substantial use of digital language by young people in their everyday lives. It could be argued that one of the main reasons for this is that the students, within a formal and conventional environment, such as university, are not used to, and, therefore, have difficulty in, engaging with a learning method that is not traditional, in both the tool used and the requirement of expressing individual opinions by engaging with and negotiating the knowledge of other students. The fact that two-thirds of the course hours ( 32 hours) took place face to face, with the resulting familiarity with the other students in the forum, together with the fact that discussions were launched in a classroom environment, does not seem to have mitigated this issue.

It appears that a mainly structured environment and discussions that are monitored and stimulated by the teacher are necessary (Guerra, 2015) in order to develop learning procedures in the form of social constructivism (and also postconstructivism), for example, picking up on contrasting views and re-proposing them in the debate to focus on various 
points of view, asking for clarification, providing further material for research and re-proposing individuals' decontextualised contributions in the discussion.

A further significant aspect to this is the importance of students who spontaneously take on the role of tutor within the digital environment. In the experience described here, this happened on various occasions: one student in particular, thanks to his/her cognitive maturity in relation to his/her age, contributed to discussions numerous times, encouraging discussion, meta-cognitively reflecting on the process, focusing on a specific and previously unconsidered aspect of a problem, and summarising the contributions of others. It is clear that if the aim is to encourage not so much the negotiation but the genuine cooperative building of knowledge, it would be necessary to form groups, giving each member a specific role (Cesaresi \& Cacciamani, 2015), explaining their main characteristics and functions (Ferrari, 2015). In such a learning context, it would be possible and very interesting to analyse in more detail than it was possible in these pages the dynamics of negotiating knowledge, building a sense of identity (Ligorio, 2009) and building social consensus deriving from communicative exchanges.

\section{References}

Ajello, A. M., Pontecorvo, C., Zucchermaglio, C. (1991). Discutendo si impara. Roma: Carocci.

Ardizzone, P., Rivoltella, P. C. (2003). Didattiche per l'e-learning. Metodi e strumenti per l'innovazione dell'insegnamento universitario. Roma: Carocci.

Cacciamani, S., Ferrini, T. (2007). Costruire conoscenza in un corso universitario on line è davvero possibile?, TD Tecnologie Didattiche , 40 (1), 28-36.

Cacciamani, S., Cesareni, D., Martini, F., Ferrini, T., Fujita, N. (2012). Influence of participation, facilitator styles, and metacognitive reflection on knowledge building in online university courses. Computers \& Education, 58 (3), 874 884.

Cacciamani, S., Cesareni, D., Ligorio, M. B. (2013). Knowledge building Community: evoluzione e applicazioni. In D. Persico \& V. Midoro (Eds.), Pedagogia nell'era digitale. (pp. 30-36). Ortona: Menabò.

Calvani A. (2005). Rete, comunità e conoscenza: costruire e gestire dinamiche collaborative. Trento: Erickson.

Calvani A., Varisco B.M. (Eds.) (1995), Costruire/decostruire significati. Ipertesti, micromondi e nuovi orizzonti formativi, Padova: CLEUP.

Cesareni, D., Ligorio, M. B., Pontecorvo, C. (2001). Discussione e argomentazione in un forum universitario, $T D$ Tecnologie Didattiche, 24 (3), 55-65.

Cesareni D., Martini, F. (2005). Costruire conoscenza in un forum universitario, Rassegna di Psicologia, XXII (1), 89112.

Cesaresi, D., Cacciamani, S. (2015). Assunzione di ruolo e funzioni conversazionali in un corso universitario "blended". TD - Tecnologie Didattiche, 23 (3), 139-147.

Fabbri, M. (2009). Insegnare all'Università nella prospettiva del Web 2.0. Il Forum come ambiente di formazione, $R P D$ - RICERCHE DI PEDAGOGIA E DIDATTICA, 2009, 4, 1001-1027.

Ferrari, L. (2015). Costruire esperienze didattiche di online collaborative learning. Parma: Edizioni Junior.

Garrison, R., Anderson, T. (2003).E-learning in the 21st century. A framework for research and practice. London and

New York: Routledge Falmer.

Garrison, D. R., Anderson, T., \& Archer, W. (2000). Critical inquiry in a text-based environment: Computer conferencing in higher education. The Internet and Higher Education, 2 (2-3), 1-19.

Guerra, L. (Ed.) (2002). Educazione e tecnologie. I nuovi strumenti della mediazione didattica. Bergamo: Edizioni Junior.

Guerra, L. (2015). Didattiche digitali: tra mitologie e nuove sfide educative. In L. Ferrari, Costruire esperienze didattiche di online collaborative learning (pp. 9-15). Parma: Edizioni Junior.

Henri, F. (1992). Computer conferencing and content analysis. In A.R. Kaye, (Ed.), Collaborative Learning Through Computer Conferencing: The Najaden Papers (pp. 115-136). New York: Springer.

Jenkins, H. (2006). Convergence Culture: Where Old and New Media Collide. New York: New York University Press.

Jonassen, D. H. (1994). Thinking Technology: Toward a Constructivist Design Model, Educational Technology, 34 (4), 34-37.

Ligorio, M. B. (2009). Identity as a product of knowledge building: The role of mediated dialogue, Qwerty, IV, 1, 3346.

Muukkonen, H., Hakkarainen, K. e Lakkala, M. (1999). Collaborative technology for facilitating Progressive Inquiry: The future Learning Environment tools. In C. Hoadley \& J. Roschelle, (Eds.), Proceedings of the CSCL ' 99 conference. December 12-15, Palo Alto, Mahwah, (pp. 406-415). NJ: Lawrence Erlbaum and Associates.

Pontecorvo, C., Ajello, A. M., Zucchermaglio, C. (1995). I contesti sociali dell'apprendimento. Milano: LED.

Pozzi, F., Manca, S., Persico, D., Sarti, L. (2007). A general framework for tracking and analysing learning processes in computer-supported collaborative learning environments, Innovations in Education and Teaching International, $44: 2,169-179$. 
Rossi, P. G. (2009). Tecnologia e costruzione di mondi. Post-costruttivismo, linguaggi e ambienti di apprendimento. Roma: Armando Editore.

Rotta, Ranieri, M. (2005). E-tutor: identità e competenze. Un profilo professionale per l'e-learning. Trento: Erickson. Scardamalia, M., Bereiter, C. (1992). An Architecture for Collaborative Knowledge Building. In De Corte et al (Eds.), Computer Based Learning Environments (pp. 41-67). Berlin: Springer Verlag.

Scardamalia, M., Bereiter, C. (1994). Computer support for knowledge building communities. Journal of the Learning Sciences, 3, 265-283.

Scardamalia, M., \& Bereiter, C. (2003). Knowledge building environments: Extending the limits of the possible in education and knowledge work. In DiStefano, A., Rudestam, K.E., Silverman, R. (Eds.), Encyclopedia of distributed learning. Thousand Oaks, CA: Sage Publications.

Schön, D. A. (1993). Il professionista riflessivo. Per una nuova epistemologia della pratica professionale. Bari: Edizioni Dedalo.

Schön, D. A. (2006). Formare il professionista riflessivo. Per una nuova prospettiva della formazione e dell'apprendimento nelle professioni. Milano: Franco Angeli.

Spadaro, P. (2004). Come analizzare il discorso nei forum: come e di cosa si parla.Form@re Open Journal per la formazione in rete. 24, http://formare.erickson.it/wordpress/it/2004/come-analizzare-il-discorso-nei-forum-come-edi-cosa-si-parla/

Trentin, G. (2005). Apprendimento cooperativo in rete: un possibile approccio metodologico alla conduzione di corsi universitari online. TD - Tecnologie didattiche, 36 (3), 47-61.

Varisco, B.M. (2002). Costruttivismo socio-culturale. Roma: Carocci.

Wenger, E. (1998). Communities of practice: Learning, meaning and identity. Cambridge, UK: Cambridge University Press.

Wilson T., Whitelock, D. (1997). Come lo hanno usato? Il coinvolgimento degli studenti di informatica in un ambiente CMC creato per l'apprendimento a distanza. TD - Tecnologie didattiche, 12, 15-20. 